\title{
The Foundation of Islam, the Spirit of Pancasila to Shape the Character of the 2045 Golden Generation: A Literature Review
}

\author{
Joni Achmad Saputra ${ }^{1}$ Sowiyah $^{2}$, Fajar Ahmad Ginanjar ${ }^{3}$, Alifa Soraya Nuryadika ${ }^{4}$ \\ ${ }^{1,3,4}$ Student of Education Administration, Universitas Lampung, Bandar Lampung, Indonesia \\ ${ }^{2}$ Lecturer of Education Administration, Universitas Lampung, Bandar Lampung, Indonesia
}

\begin{abstract}
To find out the foundation of Islam, the soul of Pancasila to shape the character of the 2045 Golden Generation. The review process starts with a search engine (google scholar) to search for articles. Searches range from 2013-2020. Most of the research results show that Pancasila is the implementation of Islamic teachings so that practicing the values of Pancasila is part of worship in accordance with Islamic teachings and practicing Islam as a form of devotion and loyalty to the Indonesian nation Pancasila (Five Pillars) with values that able to build the character of youth in facing the challenges of the 2045 Golden Generation. The great hope is that in 2045 Indonesia will be filled with a generation that has noble character and has the spirit of Pancasila so that good character is formed, with the character instilled in the golden generation must be based on three aspects, namely the value of honesty, the value of truth and the value of justice. The character of the 2045 Golden Generation is the main force in building the nation's future. So it is very important that the application of Pancasila values in the midst of society is synergized again with religious teachings in schools and further education institutions to students and the nation's generation, in order to support the integrity of the Unitary State of the Republic of Indonesia (NKRI), independence, sovereignty, and shape the character of the Generation. Gold 2045.
\end{abstract}

KEYWORDS: Character, Islamic foundation, Pancasila soul, Values, 2045 golden generation

\section{INTRODUCTION}

Indonesia is one of the nation states with the largest Muslim majority population in the world. Indonesia's independence cannot be separated from Islam either. Basically, Islam and Pancasila are two things that cannot be separated because they both aim to create peace on earth. Indonesia must be able to shape its people into a nation without feeling guilty about its God, as well as religion without betraying its nation. Making religion to fill Pancasila so that it does not conflict with God and creating the principles contained in Pancasila that are in line with Islam. So the hope of the founding fathers is that Pancasila is the implementation of Islamic teachings so that practicing the values of Pancasila is part of worship in accordance with Islamic teachings and practicing Islam as a form of devotion and loyalty to the Indonesian nation (Musolin, 2020). Pancasila has a role and function in the life of the nation and state. Its role and function is as the basis of the state, ideology and way of life of the nation. As the basis of the state, Pancasila functions to regulate all government processes and at the same time become the source of all sources of law (Wijaya, 2018). Pancasila as a unifying tool of the nation has actually been in the hearts of every Indonesian, even long before independence. Pancasila is the guideline for living together in the life of the Indonesian nation. Pancasila strengthens the life of the nation and strengthens brotherhood among others in the social life of citizens (Adha \& Susanto, 2020).

The golden generation is the dream of the Indonesian nation after undergoing a period of independence for exactly one century. The golden generation is expected to be formed in 2045, the most important momentum in the history of Indonesian civilization. The big hope is that in 2045 Indonesia will be filled with generations who have noble character and have a Pancasila spirit so that good characters are formed (Amini, Abdurrahman, Syaharuddin, Tuningsih, \& Agustina, 2020). The character of the 2045 Golden Generation is the main force in building the nation's future. Education facing 2045 should be able to build the character of the golden generation of 2045 so that they have a positive attitude, essential mindset, normative commitment and ability competence. Character should be seen as the overall traits of a personality, which color the entire behavior of a person. This is the essence of a character concept (Umairah, 2017). So it is very important that the application of Pancasila values in the community is synergized again with religious teachings in schools and further educational institutions to students and the nation's generation, in order to support the integrity of the Unitary State of the Republic of Indonesia (NKRI), independence, sovereignty, and shape the Character of the 


\section{International Journal of Current Science Research and Review}

ISSN: 2581-8341

Volume 04 Issue 12 December 2021

DOI: 10.47191/ijesrr/V4-i12-08, Impact Factor: 5.825

IJCSRR@ 2021

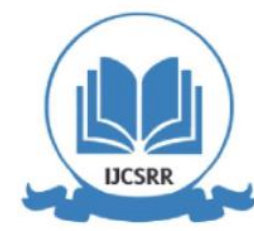

www.ijcsrr.org

Generation. Gold 2045. Because essentially no religion teaches about bad attitudes and behavior to all humans. Therefore, it is fitting that Indonesia, which is the largest Muslim majority in the world, becomes a mirror for other countries in carrying out activities in all fields that always uphold noble values, good character/akhlaqul karimah which is reflected in the teachings of the Islamic religion which guided in the Qur'an and Al-Hadith.

\section{LITERATURE REVIEW}

\section{The Foundation of Islam, The Soul of Pancasila}

Indonesia was founded on the basis of Pancasila which adheres to the principle of nationality, meaning the basis of equality as an Indonesian nation, not on the basis of similarity in religion, ethnicity, or culture. The values of Islamic law are implicitly and explicitly contained in each of the precepts in Pancasila (Haq, 2013). Differences regarding the state foundation to be taken as the basis of the state have occurred since 1938 until the preparations for the independence of the Republic of Indonesia, this difference of opinion occurred between Soekarno's nationalist group and the Islamic group led by Muhammad Natsir who wanted an Islamic state as the foundation of the state. The Nationalist group wanted Pancasila as the basis of the state while the Islamic group wanted Islam as the basis of the state, the differences in religious and state views between Soekarno and Natsir began with an article from Soekarno with the title "Why Turkey Separates Religion and the State" in 1940 (Fathani \& Qodir, 2020).

Pancasila is the philosophy of the nation and the basis of the Indonesian state, which should be the basic framework for the norms of a dignified state and society (Khotimah, 2020). Pancasila is the spirituality that underlies the Unitary State of the Republic of Indonesia. That is, he is first of all the spirit that revives the Indonesian nation. In that context, the life of the Indonesian people must be guided by five principles inspired by the "love of freedom": First, it is important to live spirituality in Indonesia in the spirit of the One Godhead who respects freedom (freedom) in believing in God. Faith in God is expressed in respect for the freedom of every human being to choose to follow their own way of believing in God. In the context of a pluralistic religion, this spirit is actualized in an attitude of tolerance among religious and belief communities (Tanamal \& Siagian, 2020). Indonesia has Pancasila as the foundation of the country which has countless philosophical values. Pancasila will underlie the character education needed by the Indonesian people to face challenges in an increasingly uncertain/disruptive era. With character education based on Pancasila values, it is hoped that Indonesia will be able to face the challenges of achieving a Golden Indonesia in 2045 (Riyanti, 2020).

\section{Character of The 2045 Golden Generation}

Pancasila towards the 2045 Golden Generation as character building for the generation is more relevant to be carried out starting from within or at home, at school it must be based on Pancasila values in society through categorical upgrading. Ki Hadjar Dewantara called it an educational trilogy. Families, schools and communities become the motor of character building and mentality of the golden generation. First, the family plays an important role in shaping the character of the golden generation. The habit of mutual respect, respect, and acceptance of differences when carried out by parents at home will actually help shape character and get used to these values. Second, the school is the second home for the golden generation that determines the pattern of life and the lives of students in social interactions and other life activities. Third, the community. The community environment as part of the educational environment also has a big role in efforts to educate the nation's children (Abi, 2017).

Character refers to a series of attitudes (attitudes), behavior (behaviors), motivation (motivations), and skills (skills). Character is a planned effort to help people understand, care about, and act on ethical/moral values. This character education teaches habits of thought and action that help people live and work together as family, friends, neighbors, community and nation (Datuk, 2019). The key to success in facing the challenges of the golden generation lies in the quality of Indonesian human resources (HR) who are reliable and cultured. Therefore, improving the quality of human resources (HR) from an early age is an important thing that must be seriously considered. National character is an important aspect of the quality of human resources (HR) because the quality of the nation's character determines the progress of a nation. Quality characters need to be formed and nurtured from an early age.

Noble character means that the individual has knowledge of his potential, which is characterized by values such as reflective, confident, rational, logical, critical, analytical, creative and innovative, independent, healthy living, responsible, love science, patient, careful , self-sacrificing, brave, trustworthy, honest, keeping promises, fair, humble, ashamed to do wrong, forgiving, softhearted, loyal, hardworking, diligent, tenacious, thorough, initiative, positive thinking, disciplined, anticipatory, initiative, visionary, unpretentious, passionate, dynamic, thrifty/efficient, respecting time, dedication/dedication, self-control, productive, friendly, love beauty (aesthetic), sportsmanship, steadfast, open, orderly (SA, 2019). 


\section{International Journal of Current Science Research and Review}

ISSN: 2581-8341

Volume 04 Issue 12 December 2021

DOI: 10.47191/ijesrr/V4-i12-08, Impact Factor: 5.825

Talking about personality formation cannot be separated from how we shape the character of human resources (HR). The formation of the character of human resources (HR) is vital and a necessity to create a new Indonesia, namely an Indonesia that can face regional and global challenges now and in the future.

\section{METHOD}

This research can be categorized as a literature review research. The purpose of conducting a literature review is to obtain a theoretical basis that can support solving the problem being studied. The review process begins with a search engine, Google Scholar, to search for articles by keywords. "Islamic Foundations, the Spirit of Pancasila to Shape the Character of the 2045 Golden Generation". The search ranged from 2013-2020 and identified a total of 50 studies and articles. The criteria for inclusion in this study were as follows:

a. Qualitative results from the Islamic Foundation, the Spirit of Pancasila to Shape the Character of the 2045 Golden Generation

Research conducted in the world.

b. This research uses English.

c. Dissertations and theses are excluded.

The steps in the literature review of each variable of the Islamic Foundation, the Soul of Pancasila to Shape the Character of the 2045 Golden Generation include:

Step1: Formulate the Problem

- Choose a topic that fits your issues and interests.

- Problems must be written completely and accurately.

Step 2: Search Literature

- Search literature relevant to research.

- Get an overview (overview) of the research topic.

- Sources of research resources are very helpful if they are supported by knowledge of the topic being studied.

- These sources provide an overview/summary of previous research.

Step 3: Data Evaluation

- Look at any contributions to the topics covered.

- Search and find the right data sources as needed to support research.

- Data can be in the form of quantitative data, qualitative data or data that comes from a combination of both.

Step 4: Analyze and Interpret

- Discuss and find and summarize literature.

\section{RESULTS AND DISCUSSION}

Table. I Islamic Foundations, The Spirit of Pancasila to Shape the Character of the 2045 Golden Generation

\begin{tabular}{|c|c|c|c|c|c|}
\hline $\begin{array}{c}\text { Author and } \\
\text { Year }\end{array}$ & Title & Country & Method & Sample & Result \\
\hline $\begin{array}{l}\text { Adha, \& } \\
\text { Susanto } \\
(2020)\end{array}$ & $\begin{array}{l}\text { The Strength of Pancasila } \\
\text { Values in Building the } \\
\text { Personality of Indonesian } \\
\text { Society. }\end{array}$ & Indonesia & Qualitative & & $\begin{array}{l}\text { Pancasila has provided a strong } \\
\text { bond of unity and integrity in the } \\
\text { midst of changes in people's lives in } \\
\text { the era of globalization, Pancasila } \\
\text { provides the strength to lead the } \\
\text { Indonesian nation to an era of glory } \\
\text { as a dignified nation in civilization. }\end{array}$ \\
\hline $\begin{array}{l}\text { Tanamal, \& } \\
\text { Siagian, } \\
(2020)\end{array}$ & $\begin{array}{l}\text { Pancasila as the Visional } \\
\text { Foundation for the } \\
\text { Spirituality of the } \\
\text { Indonesian Nation's Life in } \\
\text { Dealing with Intolerance }\end{array}$ & Indonesia & Qualitative & & $\begin{array}{l}\text { The implementation of Pancasila } \\
\text { values has not been optimal in the } \\
\text { face of radicalism and terrorism, } \\
\text { thus affecting the ideological } \\
\text { resilience which in turn has an }\end{array}$ \\
\hline
\end{tabular}


ISSN: 2581-8341

Volume 04 Issue 12 December 2021

DOI: 10.47191/ijcsrr/V4-i12-08, Impact Factor: 5.825

\begin{tabular}{|c|c|c|c|c|c|}
\hline & & & & & $\begin{array}{l}\text { impact on national security. The } \\
\text { visional foundation of Pancasila } \\
\text { needs to be understood correctly and } \\
\text { precisely. }\end{array}$ \\
\hline $\begin{array}{l}\text { Wijaya, } \\
(2018)\end{array}$ & $\begin{array}{l}\text { Revitalisasi Program } \\
\text { Pedoman Penghayatan dan } \\
\text { Pengamalan Pancasila (P4) } \\
\text { Pada Jenjang Sekolah } \\
\text { Dasar (SD) Untuk } \\
\text { Membentuk Generasi } \\
\text { Emas } 2045 \text { Bermoral } \\
\text { Pancasila }\end{array}$ & Indonesia & Qualitative & & $\begin{array}{l}\text { The revitalization strategy of the P4 } \\
\text { program can be carried out by means } \\
\text { of conditioning patterns, examples, } \\
\text { activities inside and outside the } \\
\text { classroom by involving parents, } \\
\text { schools and the community. }\end{array}$ \\
\hline $\begin{array}{l}\text { SA, U. D. } \\
(2019) .\end{array}$ & $\begin{array}{l}\text { Pendidikan Karakter } \\
\text { Pancasila Pada Era Native } \\
\text { Democracy }\end{array}$ & Indonesia & Qualitative & & $\begin{array}{l}\text { The era of native democracy that is } \\
\text { currently growing requires a strong } \\
\text { ideological basis as a source of } \\
\text { internalizing values in education. By } \\
\text { formulating character education that } \\
\text { is sourced from the values of } \\
\text { Pancasila, it will produce a golden } \\
\text { generation of } 2045 \text { as the peak } \\
\text { momentum of a century of } \\
\text { celebration of Indonesia's } \\
\text { independence. }\end{array}$ \\
\hline $\begin{array}{l}\text { Amini, et.al } \\
(2020) \text {. }\end{array}$ & $\begin{array}{l}\text { Goes To School: Sebuah } \\
\text { Kegiatan Menginspirasi } \\
\text { Siswa Menuju Generasi } \\
\text { Emas Indonesia }\end{array}$ & Indonesia & Qualitative & 15 Siswa & $\begin{array}{l}\text { The results show a fairly high } \\
\text { motivation and enthusiasm, as many } \\
\text { as } 98 \% \text { of students feel inspired to } \\
\text { stay in school well in order to } \\
\text { achieve the goals they conveyed } \\
\text { during the activity. }\end{array}$ \\
\hline Datuk, (2019) & $\begin{array}{l}\text { Pendidikan } \\
\text { Muhammadiyah dalam } \\
\text { Memantapkan Karakter } \\
\text { Siswa Di SMA } \\
\text { Muhammadiyah Kupang } \\
\text { untuk Menyiapkan } \\
\text { Generasi } 2045 .\end{array}$ & Indonesia & Qualitative & & $\begin{array}{l}\text { The generation of sons and } \\
\text { daughters born today, as well as } \\
\text { those currently in primary and } \\
\text { secondary education in } 2045 \text {, will be } \\
\text { in a productive age. They are the } \\
\text { ones who will determine the future } \\
\text { of this nation. In the preparation } \\
\text { period until 2045, it is hoped that } \\
\text { education in Muhammadiyah } \\
\text { schools must continue to advance in } \\
\text { grades in the midst of global life. }\end{array}$ \\
\hline $\begin{array}{l}\text { Amini, et.at } \\
(2020)\end{array}$ & $\begin{array}{l}\text { Nilai Maqasid Al Syariah } \\
\text { Dalam Pancasila Sebagai } \\
\text { Dasar Negara Kesatuan } \\
\text { Republik Indonesia. }\end{array}$ & Indonesia & Qualitative & & $\begin{array}{l}\text { Efforts to clash Pancasila with Islam } \\
\text { is something that is in vain because } \\
\text { contextually between Islam and } \\
\text { Pancasila do not conflict with each } \\
\text { other and precisely by implementing } \\
\text { Pancasila is the same as practicing } \\
\text { Islamic teachings. }\end{array}$ \\
\hline
\end{tabular}




\section{International Journal of Current Science Research and Review}

ISSN: 2581-8341

Volume 04 Issue 12 December 2021

DOI: 10.47191/ijesrr/V4-i12-08, Impact Factor: 5.825

IJCSRR@ 2021

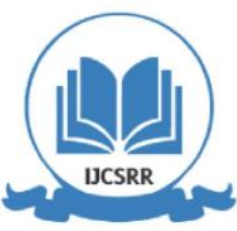

www.ijesrr.org

\begin{tabular}{|c|c|c|c|c|}
\hline $\begin{array}{l}\text { Fathani, \& } \\
\text { Qodir (2020). }\end{array}$ & $\begin{array}{l}\text { Agama Musuh Pancasila? } \\
\text { Studi Sejarah dan Peran } \\
\text { Agama Dalam Lahirnya } \\
\text { Pancasila. Al-Qalam }\end{array}$ & Indonesia & Qualitative & $\begin{array}{l}\text { The formulation of the nation's } \\
\text { ideology, religion has a big role in } \\
\text { the birth of Pancasila, the generosity } \\
\text { of several Islamic figures in the } \\
\text { formation of Pancasila and erasing } \\
\text { the seven words in the Jakarta } \\
\text { Charter is a form of maturity in } \\
\text { attitude in uniting Indonesian people } \\
\text { who come from various } \\
\text { backgrounds. }\end{array}$ \\
\hline $\begin{array}{l}\text { Khotimah, } \\
(2020)\end{array}$ & $\begin{array}{l}\text { Penerapan Pancasila } \\
\text { Perspektif Islam }\end{array}$ & Indonesia & Qualitative & $\begin{array}{l}\text { The values of Pancasila are not } \\
\text { substantially contradictory or even } \\
\text { in accordance with Islam. }\end{array}$ \\
\hline Abi, (2017) & $\begin{array}{l}\text { Paradigma Membangun } \\
\text { Generasi Emas Indonesia } \\
\text { Tahun } 2045\end{array}$ & Indonesia & Qualitative & $\begin{array}{l}\text { Education is a very central medium } \\
\text { in preparing the golden generation, } \\
\text { especially its character. The } \\
\text { character that must be built must be } \\
\text { holistic and comprehensive based on } \\
\text { Pancasila. Education not only } \\
\text { transfers knowledge but also values, } \\
\text { especially character. The character } \\
\text { instilled in the golden generation } \\
\text { must be based on three aspects, } \\
\text { namely the value of honesty, the } \\
\text { value of truth and the value of } \\
\text { justice. }\end{array}$ \\
\hline $\begin{array}{l}\text { Riyanti, et.al } \\
(2020)\end{array}$ & $\begin{array}{l}\text { The Role of Pancasila } \\
\text { Education in Shaping } \\
\text { Youth's Character Towards } \\
\text { Golden Indonesia } 2045\end{array}$ & Indonesia & Qualitative & $\begin{array}{l}\text { Based on Pancasila (Five Pillars) } \\
\text { with values that are able to build the } \\
\text { character of youth in facing the } \\
\text { challenges of one hundred years. In } \\
\text { this case, universities play a central } \\
\text { role in shaping the character of the } \\
\text { younger generation which must be } \\
\text { in line with the values of Pancasila. }\end{array}$ \\
\hline
\end{tabular}

This section reports the main findings of the articles reviewed. The analysis shows that most of the articles focus on the foundation of Islam, the soul of Pancasila to shape the character of the 2045 Golden Generation. The articles that have been reviewed are research conducted in Indonesia.

Based on the articles reviewed, there are various ways of collecting data related to the Foundation of Islam, the Soul of Pancasila to Shape the Character of the 2045 Golden Generation. The research method used is from article to article. The most commonly used method is by using interviews and observations used by (Adha \& Susanto, 2020), (SA, 2019), (Amini, 2020), (Fathani \& Qodir, 2020), (Khotimah, 2020), (Abi, 2017) and (Riyanti, 2020).

Pancasila is an implementation of Islamic teachings so that practicing the values of Pancasila is part of worship in accordance with Islamic teachings and practicing Islam as a form of devotion and loyalty to the Indonesian nation Pancasila (Five Pillars) with values that are able to build the character of youth in facing the challenges of the next generation. Gold 2045. The big hope is that in 2045 Indonesia will be filled with generations who have noble character and have the spirit of Pancasila in order to form good characters, with the character instilled in the golden generation must be based on three aspects, namely the value of honesty, the value of truth 


\section{International Journal of Current Science Research and Review}

ISSN: 2581-8341

Volume 04 Issue 12 December 2021

DOI: 10.47191/ijcsrr/V4-i12-08, Impact Factor: 5.825

IJCSRR@ 2021

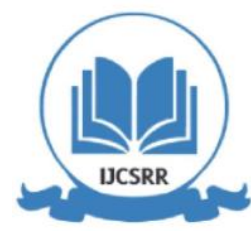

Www.ijcsrr.org

and the value of justice. The character of the 2045 Golden Generation is the main force in building the nation's future. So it is very important that the application of Pancasila values in the community is synergized again with religious teachings in schools and further educational institutions to students and the nation's generation, in order to support the integrity of the Unitary State of the Republic of Indonesia (NKRI), independence, sovereignty, and shape the character of the Generation. Gold 2045.

Research on the Islamic Foundation, the Spirit of Pancasila to Shape the Character of the 2045 Golden Generation has been carried out in Indonesia and has been carried out in various organizations. Table 1 shows that the research has been conducted in schools, universities, and schools. The results of the research mostly show that the foundation of Islam, the soul of Pancasila to shape the character of the 2045 Golden Generation

\section{CONCLUSION}

Indonesia has Pancasila as the basis for the philosophy of the nation and the basis of the Indonesian state and makes religion to fill Pancasila so that it does not conflict with God and creates the principles contained in Pancasila that are in line with Islam. The 2045 Golden Generation is the future hope of the Indonesian nation. Education is a very central medium in preparing the golden generation, especially its character. The character that must be built must be holistic and comprehensive based on Pancasila-is.

\section{REFERENCES}

1. Abi, A. R. (2017). Paradigma Membangun Generasi Emas Indonesia Tahun 2045. Jurnal Ilmiah Pendidikan Pancasila dan Kewarganegaraan, 2(2), 85-90.

2. Adha, M. M., \& Susanto, E. (2020). Kekuatan Nilai-nilai Pancasila dalam Membangun Kepribadian Masyarakat Indonesia. Al-Adabiya: Jurnal Kebudayaan dan Keagamaan, 15(01), 121-138.

3. Amini, A., Abdurrahman, A., Syaharuddin, S., Tuningsih, J. R. E., \& Agustina, J. (2020). Goes to School: Sebuah Kegiatan Menginspirasi Siswa Menuju Generasi Emas Indonesia. JPMB: Jurnal Pemberdayaan Masyarakat Berkarakter, 3(1), 1016.

4. Datuk, A. (2019). Pendidikan Muhammadiyah dalam Memantapkan Karakter Siswa Di Sma Muhammadiyah Kupang untuk Menyiapkan Generasi 2045. Paper presented at the Seminar Nasional Pendidikan dan Pembelajaran 2019.

5. Fathani, A. T., \& Qodir, Z. (2020). Agama Musuh Pancasila? Studi Sejarah dan Peran Agama Dalam Lahirnya Pancasila. Al-Qalam, 26(1), 117-128.

6. Haq, H. (2013). Kandungan Nilai-Nilai Syariat Islam Dalam Pancasila.

7. Khotimah, H. (2020). Penerapan Pancasila Perspektif Islam. Tahdzib Al-Akhlaq: Jurnal Pendidikan Islam, 3(2), 81-101.

8. Musolin, M. (2020). Nilai Maqasid Al Syariah Dalam Pancasila Sebagai Dasar Negara Kesatuan Republik Indonesia. Dialog, 43(1), 59-74.

9. Riyanti, E. D., Astuti, F. T., Rahmah, P. J., \& Ayatina, H. (2020). The Role of Pancasila Education in Shaping Youth's Character Towards Golden Indonesia 2045. In 1st Progress in Social Science, Humanities and Education Research Symposium (PSSHERS 2019) (pp. 1115-1117). Atlantis Press.

10. SA, U. D. (2019). Pendidikan Karakter Pancasila Pada Era Native Democracy. El-Hamra, 4(1), 33-40.

11. Tanamal, N. A., \& Siagian, S. B. U. (2020). Pancasila Sebagai Landasan Visional bagi Spiritualitas Kehidupan Bangsa Indonesia dalam Menangani Intoleransi. Integritas: Jurnal Teologi, 2(1), 35-48.

12. Umairah, S. J. (2017). Rekonstruksi Nilai-Nilai Religius Sebagai Landasan Menyongsong Generasi Emas 2045. PROCEEDING IAIN Batusangkar, 1(2), 361-368.

13. Wijaya, I. K. W. B. (2018). Revitalisasi Program Pedoman Penghayatan dan Pengamalan Pancasila (P4) Pada Jenjang Sekolah Dasar (SD) untuk Membentuk Generasi Emas 2045 Bermoral Pancasila. Prosiding Nasional.

Cite this Article: Joni Achmad Saputra, Sowiyah, Fajar Ahmad Ginanjar, Alifa Soraya Nuryadika (2021). The Foundation of Islam, the Spirit of Pancasila to Shape the Character of the 2045 Golden Generation: A Literature Review. International Journal of Current Science Research and Review, 4(12), 1664-1669 